\title{
Ecotypic variation in phosphorus-acquisition mechanisms within marine picocyanobacteria
}

\author{
L. R. Moore ${ }^{1, *, * *}$, M. Ostrowski ${ }^{2, * *}$, D. J. Scanlan ${ }^{2}$, K. Feren ${ }^{1}$, T. Sweetsir ${ }^{1}$ \\ ${ }^{1}$ Department of Biological Sciences, University of Southern Maine, 96 Falmouth St, Portland, Maine 04103, USA \\ ${ }^{2}$ Department of Biological Sciences, University of Warwick, Gibbet Hill Road, Coventry CV4 7AL, UK
}

\begin{abstract}
Prochlorococcus and Synechococcus are major prokaryotic primary producers in the oligotrophic oceans that may be affected by the climate-related increases in nitrogen fixation and subsequent phosphorus (P) limitation in some parts of the oceans. Evidence that Prochlorococcus populations in the North Pacific subtropical gyre (NPSG) have increased over the past decades, possibly due to having a competitive advantage under conditions of P limitation, suggests aspects of their P physiology that are important for dictating their in situ success. Here, we compared the physiology of $\mathrm{P}$ acquisition and response to $\mathrm{P}$ stress (indicated by alkaline phosphatase activity, APA) among isolates of Prochlorococcus and Synechococcus representing different genotypic clades within the marine picophytoplankton lineage (sensu Urbach et al. 1998: J Mol Evol 46:188-201). The 2 Synechococcus isolates examined (WH 8102 and WH 7803) can utilize a wide variety of organic $\mathrm{P}$ sources. Of the 3 Prochlorococcus isolates examined, only the HLI genotype, MED4, is capable of growth on a variety of organic P sources. Under conditions of P starvation the 2 Synechococcus strains and Prochlorococcus MED4 exhibit significant increases in APA, above their measurable constitutive activities. The genomes of the Synechococcus strains and Prochlorococcus MED4 indicate the presence of many P-uptake and -regulatory genes required under conditions of $\mathrm{P}$ stress, including the phoA gene that encodes for an alkaline phosphatase enzyme. The other isolates of Prochlorococcus, HLII MIT 9312 and LLIV MIT 9313, have distinctly different P-stress responses. MIT 9312, which contains the same P-uptake and -regulatory genes as MED4, except for psip1 and ptrA, has no constitutive APA, but does exhibit measurable, albeit very low, activity when P starved. MIT 9313, which lacks $p h o A$ and a functional phosphate-sensing histidine kinase gene, $p h o R$, exhibits low constitutive activity that decreases when the cells become P-starved. These results show variability in P utilization and in P-stress response between the 2 genera of marine unicellular cyanobacteria, and marked differences among Prochlorococcus genotypes, implying that only certain eco/genotypes of these marine cyanobacteria will have an ecological advantage under conditions of P limitation in the oceans. This further points to the critical need to continue developing genotypic- or cell-specific tools to assess the response of the picophytoplankton community to large-scale changes in nutrient conditions in the oceans.
\end{abstract}

KEY WORDS: Marine cyanobacteria $\cdot$ Prochlorococcus $\cdot$ Synechococcus $\cdot$ Phosphorus starvation · Alkaline phosphatase activity $\cdot$ APA

\section{INTRODUCTION}

In the world's oligotrophic oceanic regions, nitrogen $(\mathrm{N})$ and iron are traditionally considered the nutrients that limit primary production (Graziano et al. 1996, Mills et al. 2004). However, at certain times of the year, phosphorus (P) may actually limit primary production.
The Mediterranean Sea appears to be P-limited during summer-stratified periods (Thingstad \& Rassoulzadegan 1995). In the North Atlantic, a seasonal P limitation (based on measurements of concentrations and ratios of $\mathrm{N}$ and $\mathrm{P}$ and alkaline phosphatase activity, APA) has been observed following increased periods of $\mathrm{N}_{2}$ fixation (Michaels et al. 1996, Wu et al. 2000, Cavender- 
Bares et al. 2001, Ammerman et al. 2003). The most dramatic example of P limitation has been documented in the North Pacific subtropical gyre (NPSG), where it appears to have undergone a climate-related shift from an $\mathrm{N}$ - to a P-limited ecosystem over the past several decades, due to increases in $\mathrm{N}_{2}$ fixation (Karl et al. 1997). Correlated with increased $N_{2}$ fixation are shifts in the total dissolved nutrients to greater concentrations of organic P compounds in the euphotic water column of the Sargasso Sea and NPSG (Bjorkman et al. 2000). This shift to P limitation may also be the cause of an observed 'domain shift' toward an ecosystem dominated by prokaryotic organisms (Karl et al. 2001). Thus, these short- and long-term shifts in P limitation are affecting rates of gross primary production and export, C:N:P stoichiometry of dissolved and particulate matter, and community structure.

The unicellular marine cyanobacterial genera, Prochlorococcus and Synechococcus, dominate the photosynthetic biomass and are responsible for a significant portion of primary production in oligotrophic ocean ecosystems (Partensky et al. 1999). However, whether these primary producers become P-limited is not clear. There is some evidence in the Red Sea (Li et al. 1998, Fuller et al. 2005) and the Mediterranean Sea (Vaulot et al. 1996) that Synechococcus populations may be P-limited, whereas Prochlorococcus populations do not appear to be (Vaulot \& Partensky 1992). On the other hand, it has recently been reported that Synechococcus predominate in the Mediterranean Sea, possibly due to their high affinity for inorganic $\mathrm{P}$ $\left(\mathrm{P}_{\mathrm{i}}\right)$ and significantly higher maximum uptake rates relative to other plankton (Moutin et al. 2002). In the NPSG Prochlorococcus populations appear to have increased over the last several decades, possibly in response to the shift towards conditions of $\mathrm{P}$ limitation (Karl et al. 2001). These results on natural populations of Prochlorococcus and Synechococcus may differ if different eco/genotypes ${ }^{1}$ of either of these genera were dominating at the time of the studies. Regardless, both genera appear to be impacted in some way by conditions of $\mathrm{P}$ limitation.

Isolates of both Prochlorococcus and Synechococcus have been categorized based on their phylogenetic relationships, which in many cases can be correlated to differences in their ecology and/or physiology. There

\footnotetext{
${ }^{1}$ Different types of marine Synechococcus and Prochlorococcus have been referred to as ecotypes, genotypes, or pigment types by different researchers. In this paper, the term 'ecotype' will refer to phylogenetic clades of Prochlorococcus that have a characteristic ecophysiology, and 'genotype' will be used when referring to phylogenetic clades of either Synechococcus or Prochlorococcus that do not yet have an associated ecophysiology
}

are 2 physiologically and genetically distinct groups of Prochlorococcus isolates: high-light-adapted isolates (HL ecotypes) and low-light-adapted isolates (LL ecotypes), which differ in their chlorophyll $b / a$ ratio, photosynthetic capabilities, copper sensitivity, nitrite utilization, and depth distributions (Moore et al. 1998, Moore \& Chisholm 1999, Rocap et al. 1999, West \& Scanlan 1999, West et al. 2001, Mann et al. 2002). The HL isolates can be further subdivided into HLI and HLII genotypes, the ecophysiological significance of which is not yet evident. Synechococcus isolates have been split into as many as 10 clades, only 2 of which have a distinctive physiology associated with them (Toledo \& Palenik 1997, Urbach et al. 1998, Toledo et al. 1999, Rocap et al. 2002, Fuller et al. 2003). Up to this point, phosphorus physiology as a potential determinant of these different eco/genotypes has not been examined.

Extensive studies of marine A Synechococcus Strain WH 7803 (Clade V) indicate that this strain can use a wide range of organic $P$ sources for growth and that $P$ limitation results in high $\mathrm{P}_{\mathrm{i}}$-uptake rates and production of a high-affinity $\mathrm{P}_{\mathrm{i}}$-binding protein (Scanlan et al. 1993, Donald et al. 1997). Examination of the P physiology of Prochlorococcus has not been as extensive, due to the difficulty in studying the physiological status of natural populations and to the difficulty in obtaining isolates of Prochlorococcus that are free of heterotrophic contaminants, i.e. axenic. Cell-cycle studies of Prochlorococcus indicate that their response to P starvation is strikingly different from that of Synechococcus (Parpais et al. 1996). Studies on the axenic Prochlorococcus sp. PCC 9511 indicated that, like Synechococcus WH 7803, this strain of Prochlorococcus can utilize a wide variety of organic P sources for growth (Rippka et al. 2000). Recent work on the elemental composition of Prochlorococcus and Synechococcus isolates under both P-replete and P-limited culture conditions indicate that their $\mathrm{C}: \mathrm{N}: \mathrm{P}$ ratios are higher than the Redfield ratio, suggesting relatively low $\mathrm{P}$ requirements and potential competitive advantage over heterotrophic bacteria and larger phytoplankton in oligotrophic oceans (Bertilsson et al. 2003, Heldal et al. 2003). A recent study by Fuller et al. (2005) indicates that natural populations of Prochlorococcus (dominated by the HLII genotype) in the Red Sea appear unaffected by P stress, whereas Synechococcus populations may have declined due to $\mathrm{P}$ limitation.

The recent availability of the complete genome sequences for motile Clade III Synechococcus WH 8102 (Palenik et al. 2003) and 3 Prochlorococcus strains (Dufresne et al. 2003, Rocap et al. 2003) has provided insight into the genetic basis relating to P ecophysiology. Synechococcus WH 8102 and HLI Prochloro- 
coccus MED4 possess most of the genes required for $\mathrm{P}$ acquisition and regulation, whereas the other 2 Prochlorococcus genomes, LL ecotypes MIT 9313 and SS120, lack several of these genes, indicating clear diversity among the Prochlorococcus ecotypes (Scanlan \& West 2002, Mary \& Vaulot 2003). This genomic information and the experiments to date are intriguing, but do not provide a complete or clear picture of how these ecologically significant cyanobacteria deal with P limitation, especially with respect to the diversity among Prochlorococcus and Synechococcus eco/genotypes. In order to gain a better understanding of the $\mathrm{P}$ physiology and to further our ecological understanding of these 2 cyanobacterial genera, we undertook a comparative assessment of the ability to utilize different $\mathrm{P}$ sources and the alkaline phosphatase response to $\mathrm{P}$ starvation for a variety of axenic strains from both genera.

\section{MATERIALS AND METHODS}

Cultures and stock growth conditions. Three axenic Prochlorococcus isolates representing 3 distinct phylogenetic lineages (MED4 [Clade HLI], MIT 9312 [Clade HLII], and MIT 9313 [Clade LLIV]) and 5 axenic Synechococcus isolates representing 4 distinct genotypes (WH 7803 [Clade V], WH 8102 and WH 8103 [Clade III], WH 8012 [Clade I], and MIT S9220 [Clade VII]) were used. All Prochlorococcus cultures and Synechococcus MIT S9220 were obtained by courtesy of S.W. Chisholm (Massachusetts Institute of Technology). Synechococcus Strains WH 7803, WH 8103, and WH 8012 were obtained from J. Waterbury (Woods Hole Oceanographic Institution), and WH 8102 was obtained from B. Brahamsha (Scripps Institution of Oceanography).

Prochlorococcus MIT 9313 and Synechococcus MIT S9220 were rendered axenic by flow cytometric sorting on a DakoCytomation MoFlo following methods outlined in Sieracki et al. (2004). Sample lines were sterilized with bleach, then rinsed with sterile MilliQ $\mathrm{H}_{2} \mathrm{O}$ before sorting. Sterile, filtered seawater was used for the sheath. In order to ensure high purity, singlesort mode with a sort envelope of 0.5 drops was used. Two cells were sorted per tube of sterile, standard Sargasso Sea water-based media (Moore et al. 2002) from a sort region positioned at the center of the flow cytometric signature specific for the culture used. Sorted cultures were followed for growth and contamination for several months before an axenic culture was verified and reliably transferable.

Stock cultures of Prochlorococcus and Synechococcus WH 8103, WH 8012, and MIT S9220 were maintained in a standard Sargasso Sea water-based medium (Moore et al. 2002) at a constant temperature of $24^{\circ} \mathrm{C}$ and $\sim 60 \mu \mathrm{mol} \mathrm{Q} \mathrm{m} \mathrm{m}^{-2} \mathrm{~s}^{-1}$ on a $14 \mathrm{~h}$ light:10 h dark cycle. Additional stock cultures of Synechococcus WH 8102 and WH 7803 were maintained in artificial seawater medium (ASW; Rippka et al. 2000), at a constant temperature of $24^{\circ} \mathrm{C}$ and constant light of $15 \mu \mathrm{mol}$

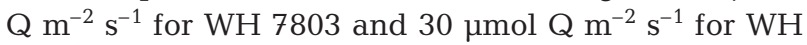
8102. All stock and experimental cultures were monitored using Marine Purity Broth (Bertilsson et al. 2003) and/or epifluorescence microscopic visualization of cultures stained with DAPI or SYBR Green (Molecular Probes) at various times to verify that they remained axenic.

Growth-capability experiments. To test the ability to grow on a variety of environmentally relevant $\mathrm{P}$ sources (Karl \& Yanagi 1997, Kolowith et al. 2001), axenic stock cultures of Prochlorococcus and Synechococcus were transferred to duplicate tubes of Sargasso Sea water-based medium containing the same trace metal mix as the stock media, $500 \mu \mathrm{M}$ $\mathrm{NH}_{4} \mathrm{Cl}$, and $10 \mu \mathrm{M}$ of $\mathrm{P}$ (tripolyphosphate $\left[\mathrm{PPP}_{\mathrm{i}}\right], \beta$ glycerophosphate [GYP], glucose-6-phosphate [G6P], adenosine triphosphate [ATP], 3', 5'-cyclic adenosine monophosphate [CAMP], or 2-aminoethylphosphonic acid [2AEP]). A control culture without added P (noP) was always grown in parallel when testing growth capability. Growth was measured by following daily changes in autofluorescence using a Turner TD-700 fluorometer or cell concentration as determined by flow cytometry (Becton-Dickinson FACS-Calibur). Additional experiments were carried out with Synechococcus WH 7803 and WH 8102 grown in duplicate in ASW medium in which $\mathrm{PO}_{4}$ was replaced by $10 \mu \mathrm{M}$ G6P, ATP, or cAMP. Growth on specific P sources was verified through serial transfers on the same P source, whereas lack of growth on a particular P source was verified by testing several times.

P-stress response experiments. To assess the Pstress response, alkaline phosphatase-like activity (APA) was measured over the growth cycle for selected isolates of Prochlorococcus (MED4, MIT 9312, and MIT 9313) and Synechococcus (WH 8102 and WH 7803). These particular experiments were carried out in different laboratories, and thus different methods for growth and APA were used, as outlined below. Despite the different methods, however, the trends in the physiological results between the 2 genera of cyanobacteria are comparable. For Prochlorococcus experiments, cells were grown in 250 or $500 \mathrm{ml}$ batch cultures containing Sargasso Sea water-based media with the trace metal mix, $250 \mu \mathrm{M} \mathrm{NH}{ }_{4} \mathrm{Cl}$ and $1 \mu \mathrm{M}$ of $\mathrm{NaH}_{2} \mathrm{PO}_{4}(\mathrm{~N}: \mathrm{P}$ $=250: 1)$. Throughout exponential growth and into the P-starved stationary phase, cell concentration was determined by flow cytometry (Becton-Dickinson FACS-Calibur), soluble reactive phosphorus (SRP) 
concentration was determined spectrophotometrically (Cary 50Bio UV/Vis-spectrophotometer; Murphy \& Riley 1962), and alkaline phosphatase activity was measured fluorometrically (SPEX FluoroMax-2) using the fluorogenic compound methylumbelliferyl phosphate (MUFP). Briefly, MUFP (200 $\mu \mathrm{M}$ final concentration) was added directly to subsamples of the cultures, and fluorescence emission of MUF product was measured at $442 \mathrm{~nm}$ as a function of time. Standard curves of MUF (Sigma, M-1508) were generated to convert the fluorescence emission data to $\mathrm{PO}_{4}$ concentrations, assuming equimolar generation of $\mathrm{MUF}$ and $\mathrm{PO}_{4}$ by APase. Rates were normalized to cell number (units of amol $\mathrm{P} \mathrm{h}^{-1}$ cell $^{-1}$ ).

Synechococcus strains were transferred to $100 \mathrm{ml}$ batch cultures of ASW containing $10 \mu \mathrm{M} \mathrm{KH}_{2} \mathrm{PO}_{4}$ for 2 successive transfers before analysis. APA was measured throughout the growth curve with the paranitrophenyl phosphate ( $\mathrm{p}-\mathrm{NPP}$ ) assay (Bessey et al. 1946) adapted for use in a microplate reader. Briefly, an aliquot of cells $(160 \mu \mathrm{l})$ was incubated with a solution of p-NPP or bis-p-NPP (18 mM, Sigma, 104 phosphatase substrate or bis-p-NPP, Acros Organics), in $1 \mathrm{M}$ Tris- $\mathrm{HCl}(\mathrm{pH} 8.0)$ to give a final concentration of $3.6 \mathrm{mM}$ p-NPP and 0.2 M Tris (pH 8.0) in $200 \mu \mathrm{l}$ (concentrations of up to $40 \mathrm{mM}$ p-NPP resulted in the same APA rates, indicating that $3.6 \mathrm{mM}$ p-NPP was saturating). The formation of product ( $\mathrm{pNP}$ ) was measured in kinetic mode over a period of $5 \mathrm{~h}$ by the change in absorbance at $405 \mathrm{~nm}$ on a Thermo Labsystems iEMS plate reader. APA was measured in triplicate from at least 3 independent experiments and calculated from the linear portion of the curve by subtracting the slope of control wells containing either no substrate or no cells. The formation of colored substrate was linear over the assay period, apart from the first $15 \mathrm{~min}$. Absorbance units were converted to pNP concentration with the extinction coefficient $1.78 \times 10^{4} \mathrm{M}^{-1} \mathrm{~cm}^{-1}$, at $\mathrm{pH} 8.0$, and a light path length of $0.32 \mathrm{~cm}$ per assay well, and then equated to $\mathrm{PO}_{4}$ following the same assumption as with the MUF conversion. Cell counts were determined by flow cytometry and used for normalizing APA values (units of amol $\mathrm{PO}_{4} \mathrm{~h}^{-1}$ cell $^{-1}$ ).

Genomic analysis. The presence (or absence) of genes involved in uptake, utilization, and regulation of $\mathrm{P}_{\mathrm{i}}$ and organic $\mathrm{P}$ were assessed from publicly available genome sequences of Prochlorococcus MED4 (GenBank Accession Number NC_005072), MIT 9313 (NC_005071), SS120 (NC_005040), and Synechococcus WH 8102 (NC_005070). The closed genome sequences of MIT 9312 (M. Coleman, C. Steglich, and S. W. Chisholm pers. comm.) and Synechococcus WH 7803 (F. Partensky pers. comm.) were made available prior to public release specifically for use in this publication. Genome annotations available in GenBank and draft annotations of WH 7803 and MIT 9312 were used to guide gene assignments. The finished MIT 9312 genome is now available at DOE's Joint Genome Institute's Microbial Genomics website (http:// genome.jgi-psf.org/microbial/). The presence or absence of genes in each genome was determined by reciprocal BLAST searches on the basis that orthologous pairs demonstrated $>50 \%$ identity over $80 \%$ of each protein sequence, unless otherwise stated. Sequence annotations were checked for frameshifts and manually refined with genome context information, multiple protein alignments (ClustalW), and identification of conserved protein domains using ScanProsite (http://us.expasy.org/prosite) and Pfam (www. sanger.ac.uk/Software/Pfam).

\section{RESULTS}

\section{Growth on various P sources}

Synechococcus WH 8103, like isolates from other genotypic clusters, is capable of using a variety of organic P sources (Fig. 1, Table 1), consistent with previous results for Synechococcus WH 7803 (Donald et al. 1997). The only exception is MIT S9220, a Synechococcus strain incapable of utilizing nitrate for growth (Moore et al. 2002), which is limited in the types of organic P that it can use for growth. Prochlorococcus HLI MED4 can grow on a wide variety of organic P sources (Table 1), consistent with findings for

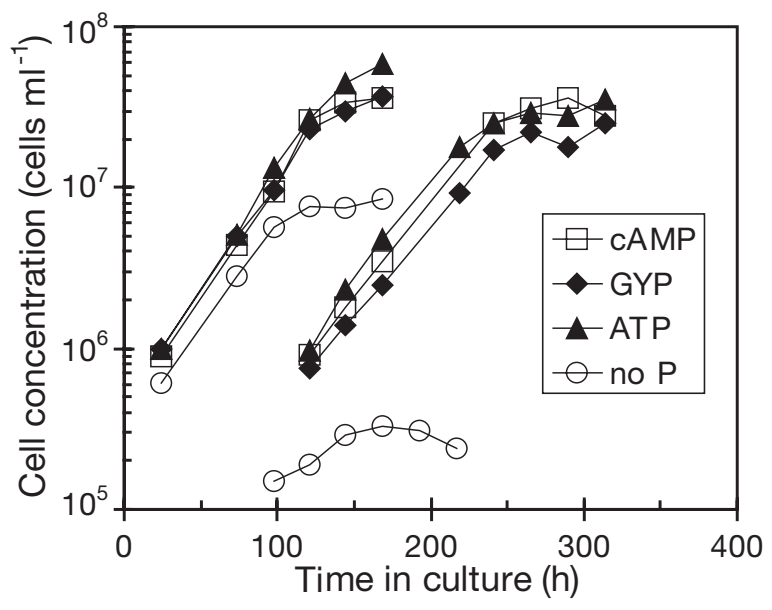

Fig. 1. Representative growth curves for Synechococcus isolate WH 8103 grown on cAMP $(\square)$, GYP $(\bullet)$, and ATP $(\boldsymbol{\Delta})$ for 2 transfers compared to response of cells when no P source was added to the media (O). Growth in the first transfer of the no $\mathrm{P}$ culture reflects the carryover of $\mathrm{P}_{\mathrm{i}}$ from the standard growth conditions of the initial parent culture. Data similar to that presented here were obtained for all the isolates tested (for abbreviations of media, see 'Materials and methods') 
Table 1. Growth capability of Prochlorococcus and Synechococcus strains (clades in parentheses) on a variety of inorganic and organic P sources. +: growth; -: no growth; +/-: inconclusive; nt: not tested

\begin{tabular}{|c|c|c|c|c|c|c|c|c|}
\hline & $\begin{array}{c}\text { MED4 } \\
\text { (HLI) }\end{array}$ & $\begin{array}{l}\text { MIT } 9312 \\
\text { (HLII) }\end{array}$ & $\begin{array}{l}\text { MIT } 9313 \\
\text { (LLIV) }\end{array}$ & $\begin{array}{c}\text { WH } 8103 \\
\text { (III) }\end{array}$ & $\begin{array}{c}\text { WH } 8102 \\
\text { (III) }\end{array}$ & $\begin{array}{c}\text { WH } 8012 \\
\text { (I) }\end{array}$ & $\begin{array}{c}\text { WH } 7803 \\
(\mathrm{~V})\end{array}$ & $\begin{array}{l}\text { MIT S9220 } \\
\text { (VII) }\end{array}$ \\
\hline $\mathrm{NaH}_{2} \mathrm{PO}_{4}$ & + & + & + & + & + & + & + & + \\
\hline Tripolyphosphate $\left(\mathrm{PPP}_{\mathrm{i}}\right)$ & + & + & + & nt & + & nt & nt & nt \\
\hline$\beta$-glycerophosphate (GYP) & + & - & - & + & + & + & + & - \\
\hline Glucose-6-phosphate (G6P) & + & - & - & nt & + & nt & + & - \\
\hline ATP & + & + & + & + & + & + & + & - \\
\hline CAMP & + & _ & _- & + & $+/-$ & - & _- & - \\
\hline 2-aminoethylphosphonate & - & - & - & nt & nt & nt & nt & nt \\
\hline
\end{tabular}

Prochlorococcus PCC 9511, which has an identical 16S rRNA gene sequence (Rippka et al. 2000). Prochlorococcus MIT 9312 and MIT 9313 can utilize ATP, with only a slight reduction in growth rate (data not shown), but not any other organic P sources that were tested. Utilization of cAMP appears to be limited to MED4 and WH 8103, whereas growth results for WH 8102 on cAMP could not be repeated consistently and, thus, are inconclusive. Consistent with previous studies (Donald et al. 1997), WH 7803 cannot utilize cAMP for growth. The ability to utilize cAMP suggests the presence of an exoenzyme capable of decyclizing cAMP, such as phosphodiesterase, followed by further hydrolysis with APase or 5'-nucleotidase. Alternatively, the cells may have the ability to take up cAMP directly (Bruns et al. 2003); however, a candidate nucleotide transporter has not been described for these cyanobacteria.

\section{Alkaline phosphatase activity}

To further characterize the $\mathrm{P}$ physiology of Prochlorococcus and Synechococcus, APA was assessed under $\mathrm{P}_{\mathrm{i}}$-replete and $\mathrm{P}$-starvation conditions through the course of the growth cycle for the 3 strains of Prochlorococcus (MED4, MIT 9312, MIT 9313) and 2 strains of Synechococcus (WH 8102 and WH 7803). P starvation in the cultures was reached when growth was saturated, as indicated by a constant cell concentration and a concomitant drop in $\mathrm{PO}_{4}$ concentration in the media to the detection limit of the method $\left.(<0.25 \mu \mathrm{M} \mathrm{PO})_{4}\right)$, as demonstrated by the results for Prochlorococcus MED4 (Fig. 2). When $\mathrm{PO}_{4}$ is present in high concentrations, Prochlorococcus isolates MED4 and MIT 9313 exhibit low ( 0.2 amol $\left.\mathrm{PO}_{4} \mathrm{cell}^{-1} \mathrm{~h}^{-1}\right)$ constitutive APA per cell, whereas MIT 9312 shows essentially none (Fig. 3A-C). The 2 Synechococcus isolates also exhibit low constitutive APA when grown in $\mathrm{P}_{\mathrm{i}}$-replete ASW ( 0.02 amol $\mathrm{PO}_{4}$ cell $^{-1} \mathrm{~h}^{-1}$, Fig. 3D,E).

When the batch cultures became starved for $\mathrm{P}_{\mathrm{i}}$, the APA responded differently for the different cultures.
MED4 exhibited a dramatic, 43-fold increase in APA (Fig. 3A). On the other hand, MIT 9312 and MIT 9313 showed small changes in their APA (8-fold increase and 2.4-fold decrease, respectively; Fig. 3B,C). Like MED4, the 2 Synechococcus isolates showed increased APA, but to differing degrees (Fig. 3D,E). WH 7803 exhibited a modest 4 -fold increase over constitutive APA levels, whereas WH 8102 exhibited an increase in APA that was biphasic. During the phase of decelerating growth, the APA jumped 6-fold relative to the low constitutive $\mathrm{P}_{\mathrm{i}}$-replete level. At the onset of the $\mathrm{P}_{\mathrm{i}}$-starved stationary phase, APA increased another 4 -fold to reach a maximum of $0.239 \pm 0.015 \mathrm{amol}^{\mathrm{PO}_{4}}$ cell $^{-1} \mathrm{~h}^{-1}$ (Fig. 3E). For both WH 7803 and WH 8102 the external $\mathrm{P}_{\mathrm{i}}$ concentration fell below detectable limits $(0.25 \mu \mathrm{M})$ at least 1 generation before the saturated growth phase was achieved (data not shown); however, the maximum APA was not achieved until after

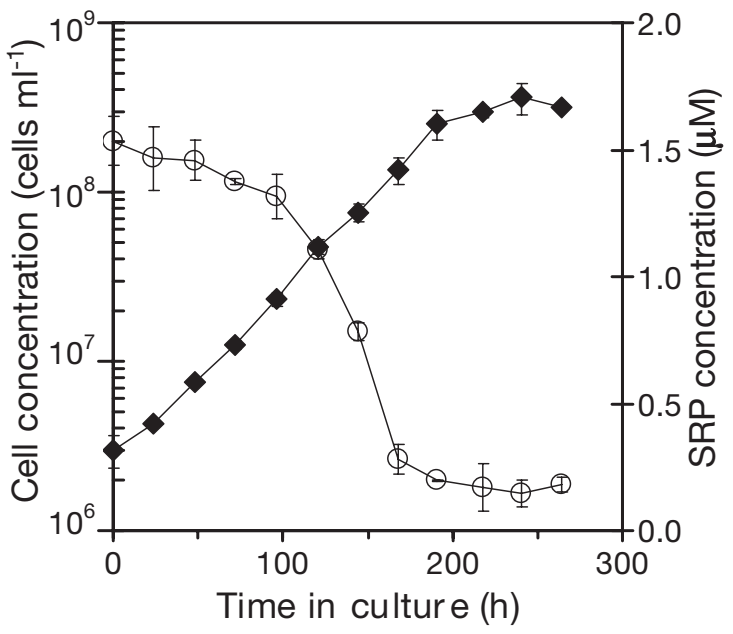

Fig. 2. Increase in cell concentration $(\diamond)$ and decrease in SRP concentration (O) versus time for Prochlorococcus MED4 grown with $\mathrm{PO}_{4}$ and used for APA measurements. Symbols and error bars represent average and standard deviation of replicate cultures. Data similar to that presented here were obtained for the other isolates used for APA measurements 

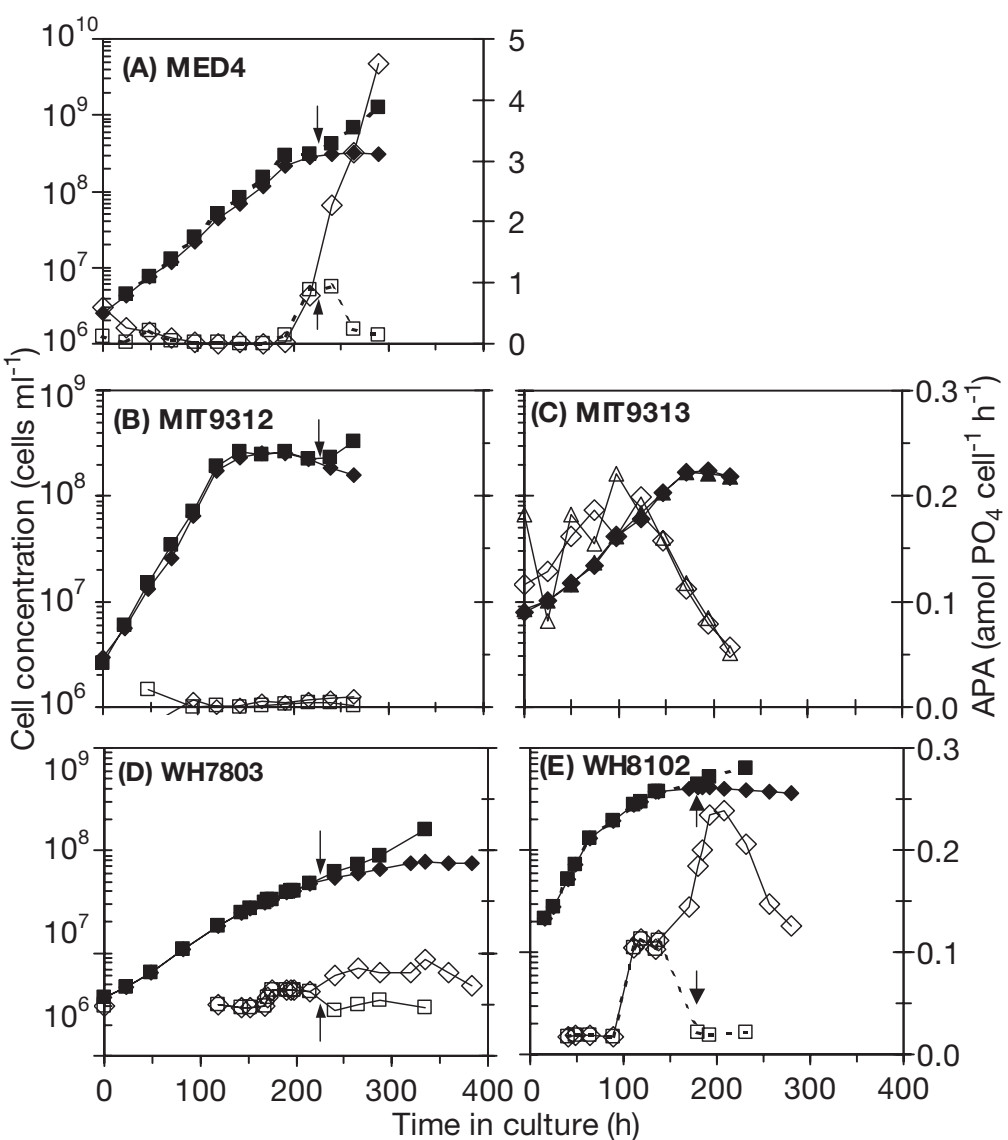

Fig. 3. Cell concentration (solid symbols) and cell-specific APA (open symbols) as a function of time for duplicate cultures of (A) Prochlorococcus MED4, (B) MIT 9312, (C) MIT 9313, and of (D) Synechococcus WH 7803 and (E) WH 8102. One replicate of each isolate (except MIT 9313) was rescued from $\mathrm{P}$ starvation by the addition of $\mathrm{PO}_{4}$ (indicated by arrows); the square symbols represent the P-rescued culture. Note: the $y$-axes for MED4 are scaled differently from the others to account for higher cell yields and APA levels in this strain

saturation. The maximum measured APA per cell for both Synechococcus strains is similar to that measured in P-deplete cultures of Synechococcus sp. PCC7942 (Ray et al. 1991), and the rates of phosphate di-esterase activity (tested with the substrate bis-pNPP) were similar to rates of monoesterase activity at all time points.

The level of APA varies with the source and concentration of P. When MED4 is grown with organic P (GYP or ATP) as the sole source of $\mathrm{P}$, the APA is 3 to 8 times higher than when $\mathrm{PO}_{4}$ is available, suggesting slight up-regulation of APase expression or activity in the presence of external organic P (Fig. 4). APA further increased in these cultures upon reaching P starvation, however, we were not able to follow the ATP-grown MED4 cultures very far into the P-starvation stage. Although these same experiments were not carried out with the Synechococcus strains, when these strains are grown in SN media (Waterbury et al. 1986) containing $75 \%$ Sargasso Sea water base and 17.4 $\mu \mathrm{M} \mathrm{PO}_{4}$, APA was 2- to 3-fold higher (data not shown) than when grown with ASW and $10 \mu \mathrm{MPO}_{4}$, suggesting an increase in APA due to the likely presence of external organic $\mathrm{P}$ in the Sargasso Sea water. On the other hand, when $\mathrm{PO}_{4}$ is added to P-starved cultures of MED4 $(10 \mu \mathrm{M}$ $\left.\mathrm{PO}_{4}\right), \mathrm{WH} 7803$ and WH $8102\left(50 \mu \mathrm{M} \mathrm{PO}_{4}\right.$ for rescuing the Synechococcus cultures), APA is repressed almost immediately (Fig. 3A,D,E), suggesting that high concentrations of $\mathrm{PO}_{4}$ inhibit APA, the enzyme(s) is actively degraded, or gene expression is repressed.

\section{Genomic comparisons}

In order to comprehend the molecular basis of the specific differences in P physiology observed, we examined the completed genomic sequences of 6 marine cyanobacteria for genes related to P acquisition and regulation. We looked specifically for the presence and absence of genes encoding phosphate-uptake systems, outer-membrane porins, regulatory systems, and phosphate-scavenging pathways, such as extracellular phosphatases in 4 Prochlorococcus strains (MED4, MIT 9313, SS120, and MIT 9312) and 2 Synechococcus strains (WH 8102 and WH 7803) (Table 2). Unlike the much-studied phosphateacquisition and -regulation system in Escherichia coli, these marine cyanobacterial genomes lack the genes associated with the low-affinity system

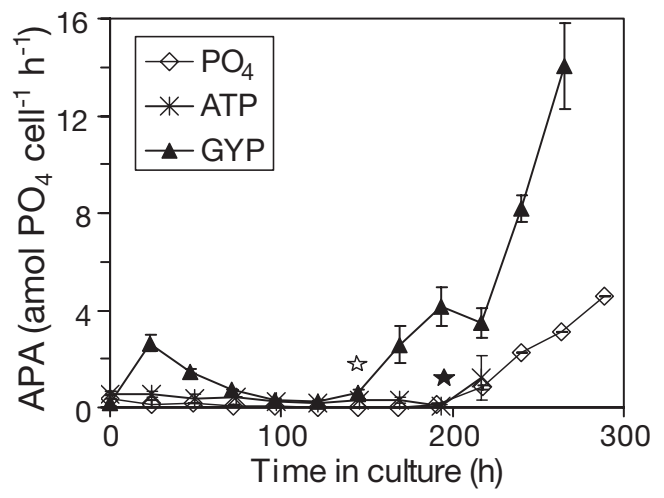

Fig. 4. MED4 average cell-specific APA as a function of time over the course of growth on $\mathrm{PO}_{4}(\diamond)$, ATP (cross-hatched symbols), and GYP $(\mathbf{\Delta})$. The stars indicate the point at which the cultures entered the stationary growth phase. The open star is for GYP cultures; the solid star is for both the $\mathrm{PO}_{4}$ and ATP cultures. Symbols and error bars represent average and standard deviation of replicate cultures 
Table 2. Phosphorus assimilation and regulatory genes present in unicellular marine cyanobacterial genomes (+: presence of the gene; -: gene is absent). The genome copy number for all genes present in the genomes is 1, except those with multiple copies indicated by the number in parentheses

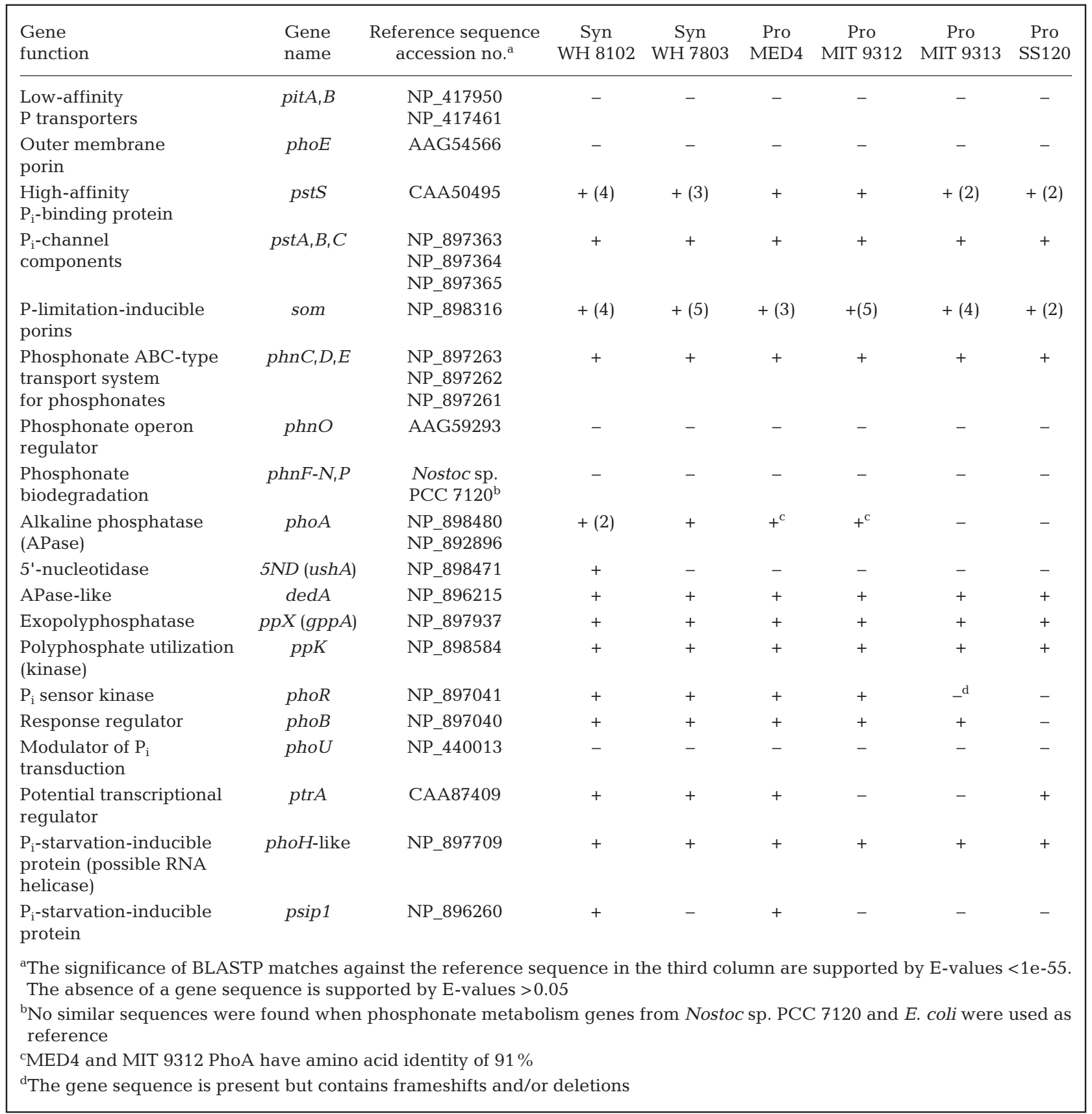

(pitAB) and homologues of the P-specific porin (phoE). However, the marine cyanobacteria contain orthologues of many components of bacterial high-affinity P-uptake systems, most notably the high-affinity periplasmic binding protein and ABC-type transport system (PstSCAB), and a number of P-limitationinducible outer-membrane porins (Som proteins). An interesting feature of marine cyanobacterial genomes is the multiplication of the pstS and som genes, which are present in multiple, nonidentical copies in all strains, with the exception of a single copy of pstS in MED4 and MIT 9312 (Table 2). In addition to the Pst ABC-type transport system, the genes for a putative phosphonate ABC transporter system, phnCDE (Palenik et al. 2003), are also conserved within the genomes studied, indicating the potential to at least 
actively transport phosphonates into the cell. However, on the basis of similarity searches, we were unable to identify genes encoding enzymes (PhnF-N,P) capable of degrading phosphonate (carbon-phosphorus) bonds or the phosphonate-operon-regulatory protein, $\mathrm{PhnO}$. The lack of phosphonate-degrading enzymes is consistent with the inability of Prochlorococcus isolates to grow with AEP. Testing additional phosphonate compounds is necessary to more fully understand the phosphonate-related physiology of Prochlorococcus and to confirm the previous report that WH 8102 is capable of growing on an unidentified phosphonate source (Palenik et al. 2003).

Apart from the potential ABC-transport system for phosphonates, no genes were identified for the transport of organic phosphates in these marine cyanobacterial genomes. This is also the case for numerous freshwater cyanobacteria that are reliant on the synthesis of periplasmic phosphatases to enable $P_{i}$ scavenging through hydrolysis of organic phosphates under $\mathrm{P}_{\mathrm{i}^{-}}$ deficient conditions (Grossman et al. 1994). Gene sequences similar to characterized APases (such as phoA) were identified in HL Prochlorococcus MED4 and MIT 9312, in Synechococcus WH 8102 and WH 7803, but not in LL Prochlorococcus ecotypes MIT 9313 or SS120 (Table 2). The phoA gene sequence for MIT 9312 has the highest sequence identity to that of the other HL Prochlorococcus MED4, which has a deduced amino acid (aa) sequence $(760 \mathrm{aa}, 83 \mathrm{kDa}$ predicted molecular weight) most similar to the predicted $79 \mathrm{kDa}$ APase of Silicibacter sp. TM1040 (Fig. 5). This suggests that the HL Prochlorococcus may have acquired their phoA gene in a lateral gene transfer event. In contrast, Synechococcus WH 8102 and WH 7803 possess different complements of phoA. The WH 7803 genome encodes 1 phoA

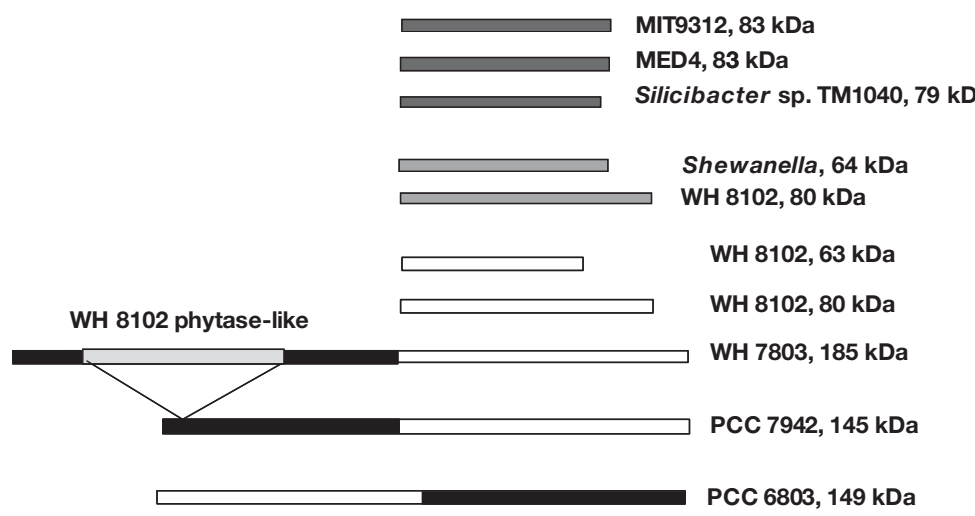

Fig. 5. Simplified alignment of domains in $p h o A$ and $p h o A$-like genes found in marine cyanobacterial and proteobacterial genomes with high sequence similarities, indicated by matched shading. Lengths of rectangles represent relative protein sizes. Predicted molecular weights (in $\mathrm{kDa}$ ) for each protein are indicated gene sequence (Fig. 5) with a predicted mass of $185 \mathrm{kDa}$ homologous to an atypical $145 \mathrm{kDa}$ APase, which is responsible for increased APA in Synechococcus sp. PCC 7942 (Ray et al. 1991) and similar to the $149 \mathrm{kDa}$ P-limitation-induced APase found in Synechocystis PCC6803 (Hirani et al. 2001). Strain PCC 7942 also contains a second constitutive (noninducible) APase of $61 \mathrm{kDa}$, designated as phoV (Wagner et al. 1995) for which no obvious homologues have been found within the genomes examined in this study. In contrast to WH 7803, WH 8102 encodes at least 3 APases (Palenik et al. 2003): an APase $(749 \mathrm{aa}, 80 \mathrm{kDa})$ similar to sequences found in $\gamma$ proteobacteria (Shewanella and Vibrio) and 2 adjacent APase genes, a predicted APase $(576 \mathrm{aa}, 63 \mathrm{kDa})$ and a predicted APase/5'nucleotidase (750 aa, $80 \mathrm{kDa}$ ), both of which are homologous to the C-terminal of the WH 7803 phoA (Fig. 5). A small ( 200 aa), putative APase-like gene, $\operatorname{ded} A$, named for its predicted transmembrane region, is also found in all the marine cyanobacterial genomes examined for this study; however, its specific function is not known.

There are also obvious differences in gene complement with respect to phosphate sensing and regulation amongst the genomes (Table 2). The HL Prochlorococcus (MED4 and MIT 9312) and the 2 marine A Synechococcus (WH 8102 and WH 7803) contain homologues of the phoR gene, encoding a sensor histidine kinase, and the $p h o B$ gene, encoding the cognate response regulator responsible for $\mathrm{P}$ sensing and regulation in a wide variety of bacteria (e.g. see Wanner 1996). LL-adapted Prochlorococcus MIT 9313 contains a phoB gene, but a nonfunctional phoR (Scanlan \& West 2002), whereas Prochlorococcus SS120 appears to lack both regulatory genes. The gene corresponding to PtrA, a putative transcriptional activator found in WH 7803 (Scanlan et al. 1997a), is also found in WH 8102, MED4, and SS120, but is missing from MIT 9312 and MIT 9313. Another regulatory gene encoding for a modulator of $\mathrm{P}_{\mathrm{i}}$ transduction,

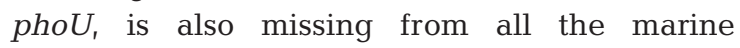
cyanobacterial genomes, but is found in the freshwater cyanobacterium Synechocystis PCC6803 (www.kazusa.or.jp/cyanobase/).

Other genes involved in $\mathrm{P}$ acquisition are also present in all 6 marine cyanobacterial genomes, including the genes involved in internal polyphosphate metabolism ( $p p K$ and $p p X$ ), consistent with the ability of the strains tested to grow with $\mathrm{PPP}_{\mathrm{i}}$ as the sole source of $\mathrm{P}$ (Table 1), and the P-starvationinduced protein, $p h o H$, believed to be an RNA helicase that is highly conserved in bacteria (Kim et al. 1993). Another gene for a P-starvation-induced protein, $p \operatorname{sip} 1$ (N. J. West \& D. J. Scanlan unpubl. data), is found in MED4 and WH 8102, but not in MIT 9312, SS120, MIT 9313, and WH 7803. 


\section{DISCUSSION}

\section{Utilization of organic $P$ sources}

The ability to utilize organic sources of phosphate varies widely among the strains of Prochlorococcus and Synechococcus tested so far. Some of the variability can be explained by presence and/or absence of P-acquisition and -scavenging genes. Synechococcus isolates from several genotypic clusters are capable of using a variety of organic P sources (Table 1), as was demonstrated previously for Synechococcus WH 7803 (Donald et al. 1997). Consistent with this ability is the presence of essential genes required for acquisition and regulation of $\mathrm{P}_{\mathrm{i}}$ under phosphate-deficient conditions. One exception is MIT S9220, a Synechococcus strain incapable of utilizing nitrate for growth (Moore et al. 2002), which cannot utilize any of the organic $P$ compounds tested. However, the genome is not available for this strain of marine Synechococcus. Like Synechococcus strains WH 8102 and WH 7803, HLI Prochlorococcus MED4 is capable of utilizing a broad range of organic $\mathrm{P}$ compounds and contains a similar suite of P-acquisition and -regulation genes. Thus, these genotypes may have an advantage in $\mathrm{P}_{\mathrm{i}}$ depleted marine waters that have greater concentrations of organic $\mathrm{P}$ compounds due to increased $\mathrm{N}_{2}$ fixation and $\mathrm{P}_{\mathrm{i}}$ depletion (Bjorkman et al. 2000).

Like freshwater cyanobacteria, marine cyanobacteria appear to be reliant on the expression of exported phosphatases, such as APase, for hydrolysis of phosphate from organic sources during periods of $\mathrm{P}_{\mathrm{i}}$ restriction. Indeed, WH 8102, WH 7803, and MED4 have at least 1 gene for APase, phoA, as well as the putative APase-like gene, $\operatorname{ded} A$, consistent with their ability to utilize various organic phosphates. Interestingly, HLII Prochlorococcus MIT 9312 contains a very similar Pacquisition gene compliment to HLI MED4, with no obvious mutations, but only utilizes ATP as an organic $\mathrm{P}$ source. The only P-related genes that MIT 9312 appears to lack relative to MED4 are psip1 and ptrA. On the other hand, the LL Prochlorococcus strains MIT 9313 and SS120 lack phoA, but contain $\operatorname{ded} A$, which may explain the ability of MIT 9313 to utilize ATP, or ATP may be taken up into the periplasm through one of the many P-limitation-induced porins.

\section{Alkaline phosphatase activity}

The ability to utilize a wide variety of organic $\mathrm{P}$ sources and the presence of APases in MED4, WH 8102, and WH 7803 are reflected in their APA. These 3 cyanobacteria express constitutive APA when $\mathrm{PO}_{4}$ is present, and then increase their APA when $\mathrm{PO}_{4}$ becomes depleted and the cells become P-starved. Unexpectedly, HLII MIT 9312, which contains essentially the same phoA as MED4, does not exhibit constitutive APA and only shows minimal increases in APA once it becomes $\mathrm{P}$ starved. Possible explanations include the lack of Psip1, which may be required for constitutive APA, and/or the lack of PtrA, which may be required for activation or enhancement of expression of genes responding to $\mathrm{P}$ limitation, such as phoA and pstSCAB. The LLIV Prochlorococcus ecotype MIT 9313, which cannot utilize many organic P compounds and does not contain a phoA equivalent, exhibits very low but measurable constitutive APA. The expression of measurable APA in this strain is possibly due to the presence of the APA-like DedA protein, though geneexpression studies are required to pin this down. The frameshift and mutation in phoR of MIT 9313 (Scanlan \& West 2002) suggest that this LL strain lacks the ability to regulate a response to $\mathrm{P}$ depletion, possibly explaining the decrease in cell-specific APA once $\mathrm{P}_{\mathrm{i}}$ becomes depleted. The total absence of $p h o B$ and phoR in SS120 implies that this LL strain also is incapable of regulating a response to $\mathrm{P}$ depletion, but determining this awaits an axenic strain of SS120, which currently is not available.

Synechococcus WH 7803 and WH 8102 exhibit similar low constitutive levels of APA when P replete $\left(>50 \mu \mathrm{M} \mathrm{PO}_{4}\right.$ ). However, after successive subculture in ASW with $10 \mu \mathrm{M} \mathrm{PO}, \mathrm{WH} 7803$ displayed a 2-fold increase in baseline AP activity, while WH 8102 maintained activity at constitutive levels. This slight difference in the pattern of APA induction hints that these strains could sense $P$ limitation at different threshold concentrations of $\mathrm{P}_{\mathrm{i}}$ or could possess different mechanisms of APA regulation. The maximum APA activity for WH 7803 and WH 8102 was not achieved until at least $120 \mathrm{~h}$ after the external $\mathrm{P}$ concentration had fallen below detectable levels. The time delay in reaching maximum APA may be due simply to a rather high detection limit for P. However, another explanation for this observation is in line with the response of Synechocystis PCC6803, where 1 of 2 operons encoding the high-affinity $\mathrm{P}$-uptake system PstSCAB is expressed during the early stages of $\mathrm{P}$ depletion, while the expression of phoA, nucH (extracellular nuclease), and the second pst operon occurs later (Suzuki et al. 2004), suggesting a distinction between P-limitation (expression of pstSCAB) and P-starvation responses (expression of pstSCAB and APA). A maximum APA was not observed for MED4 or MIT 9312, though these cultures were not followed beyond $\sim 100 \mathrm{~h}$ after $\mathrm{P}$ starvation was reached.

Another intriguing observation is that MED4, WH 8102, and WH 7803 express higher APA activity when grown in the presence of organic P. This occurs in the 
Synechococcus cultures even when the external $\mathrm{P}_{\mathrm{i}}$ concentration is relatively low $(<25 \mu \mathrm{M})$, but not preventing growth, suggesting that these strains are capable of regulating their APA in order to exploit organic and inorganic sources of P simultaneously, as observed for marine microbial communities (Bjorkman \& Karl 2003). Furthermore, the lack of a constitutive lowaffinity P-uptake system (Pit system) suggests that the high-affinity, energy-dependent $A B C$ transporter is always required for $\mathrm{P}$ uptake in the marine environment. The possession of multiple copies of the periplasmic phosphate-binding protein, possibly under differential P regulation, in HL Prochlorococcus and Synechococcus WH 8102 and WH 7803 may serve to provide a rapid response to short periods of $\mathrm{P}$ limitation. Since the energy requirements for $P_{i}$ uptake are supplied by photosynthesis (Ritchie et al. 2001), the ability to opportunistically use organic $\mathrm{P}$ at the same time would provide a significant advantage over heterotrophic competitors.

\section{Ecological implications}

Apart from the APase-like dedA genes present in all of the strains examined in this study, WH 8102, WH 7803, and the HL Prochlorococcus do not possess orthologous APase genes. In other words, the current array of APase genes among the genomes was not inherited from a common ancestor, implying that APase genes were acquired independently through horizontal gene transfer (as appears to be the case for $p h o A$ in the 2 HL Prochlorococcus) and/or loss of ancestral genes. Horizontal gene transfer is supported by the low mol\% $\mathrm{G}+\mathrm{C}$ composition of $p h o A$ sequences relative to the genome average $\mathrm{mol} \% \mathrm{G}+\mathrm{C}$ in $\mathrm{WH} 7803$ and $\mathrm{WH}$ 8102. Furthermore, the selection of different APase genes in each strain may reflect the total range of organic substrates encountered in their respective ecological niches. In general APases and 5'-nucleotidases are capable of hydrolyzing a wide range of organic P monoesters (Wagner et al. 1995, Wanner 1996). Although the substrate specificity of the APases from PCC7942 or PCC6803 have not been examined in great detail, these proteins retain domains conserved amongst alkaline phosphatases such as multiple P-loop motifs, which are thought to be involved in binding terminal $\mathrm{PO}_{4}$ moieties and could serve to extend the range of organic P substrates hydrolyzed (Ray et al. 1991, Hirani et al. 2001). In this regard the WH 7803 phoA is unusual in that it contains a 480-aa insertion in the conserved N-terminal ATPase domain of its $185-\mathrm{kDa}$ PhoA (Fig. 5). The inserted sequence is homologous with the first 580 aa of a conserved hypothetical protein found in WH 8102, which itself displays some similarity to phytase (myo-inositol hexakisphosphatase), an enzyme that hydrolyzes phytic acid or similar complex organic P-rich substrates. The presence of this unusual insertion sequence and gene raises the intriguing possibility that complex organic P-rich substrates of terrestrial origin may provide an advantage to some Synechococcus in coastal marine environments, even though phytic acid has not been identified as a component of dissolved organic phosphorus in recent coastal and open ocean surveys (Monaghan \& Ruttenberg 1999, Kolowith et al. 2001).

The P physiology presented in this study is consistent in part with the ecological niche distribution of marine cyanobacteria. LL Prochlorococcus MIT 9313 has a limited capacity to utilize organic $P$ sources and expresses extremely low levels of APA, and 2 LL Prochlorococcus (MIT 9313 and SS120) lack an obvious phoA gene and contain mutations or deletions in key P-regulatory genes, such that a P-stress response is likely not regulated. These deficiencies in $\mathrm{P}$ acquisition and regulation may reflect the fact that relatively high and constant inorganic phosphorus levels are found in the deep euphotic zone, where LL Prochlorococcus reside (Scanlan \& West 2002, Fuller et al. 2005), and precise regulation of the $\mathrm{P}$-acquisition machinery would be unnecessary. In contrast, HL Prochlorococcus and Synechococcus occupy the upper photic zone, where inorganic nutrients, such as $\mathrm{P}_{\mathrm{i}}$, are typically depleted and competition for recycled organic $\mathrm{P}$ is great (Bjorkman \& Karl 1994, Li et al. 1998, Fuller et al. 2005).

However, the results from this study and recent field observations are not entirely consistent with this simplistic model. HLII Prochlorococcus MIT 9312, which does not utilize a variety of organic P sources and does not exhibit significant levels of APA even under conditions of P starvation, would appear to be at an ecological disadvantage in P-limited surface waters compared to HLI Prochlorococcus MED4. Yet, the HLII genotype dominates natural Prochlorococcus populations in nutrient-depleted summer surface waters of the Red Sea (Fuller et al. 2005), the North Pacific (E. Zinser \& S.W. Chisholm pers. comm.), and the Sargasso Sea (Scanlan \& West 2002), implying that it may be unaffected by $\mathrm{P}$ limitation in contrast to other HL Prochlorococcus genotypes, possibly due to more efficient $P_{i}$ uptake than the HLI type, which could be due to, and reflected in, differences in gene regulation. This hypothesis awaits confirmation.

The results reported here have important implications for the use of bulk APA as an indicator of the P status of phytoplankton communities. We have shown that APA is expressed constitutively in several strains of Synechococcus and Prochlorococcus and the presence of organic P sources and conditions of P limitation 
and starvation elicit markedly different capacities to express APA and utilize organic P sources. Genomic comparisons make it clear that APA may be attributed to multiple enzymes with different regulation and substrate specificities in the Prochlorococcus and Synechococcus strains studied. It is important to note that the use of different markers for APA in this study (pNPP and MUFP) may add other confounding factors, such as differential availability of each enzyme for each substrate. Consequently, bulk APA measurements may not reflect community-wide $\mathrm{P}$ status, but rather $\mathrm{P}$ limitation of undetermined subpopulations of the phytoplankton community. Clearly more work is needed in order to define genotype-specific responses to general P stress in marine picophytoplankton, a task that will benefit greatly from in-depth analysis of diverse axenic isolates and on-going genomesequencing projects, as well as further use and optimization of methodologies that are capable of assessing $\mathrm{P}$ status at the single-cell level (Scanlan et al. 1997b, Dyhrman et al. 2002). Understanding the nutrient-stress response of specific eco/genotypes of marine picophytoplankton is critical to being able to determine the in situ nutrient status of these organisms, particularly in response to climate-related environmental changes. And more generally this work suggests that studies of nutrient enrichment on natural populations (e.g. ocean fertilization experiments) need careful interpretation given that other phytoplankton groups also likely share a plethora of eco/genotypic responses to nutrient limitation.

Acknowledgements. We would like to acknowledge G. Rocap and S. W. Chisholm for helpful discussion related to this study, and C. Steglich and M. Coleman for assistance with MIT 9312 genome data. We thank M. Sieracki and N. Poulton of the J. J. MacIsaac Aquatic Cytometry Facility at the Bigelow Laboratory for Ocean Sciences for their flow cytometry expertise that enabled the establishment of axenic MIT 9313 and MIT S9220 cultures. L.R.M. was supported by Biosciences Research Institute of Southern Maine and a USM Faculty Senate Grant. D.J.S. and M.O. were supported by the EU FP5 program Margenes (QLRT-2001-0226).

\section{LITERATURE CITED}

Ammerman JW, Hood RR, Case DA, Cotner JB (2003) Phosphorus deficiency in the Atlantic: an emerging paradigm in oceanography. EOS 84:165-170

Bertilsson S, Berglund O, Karl DM, Chisholm SW (2003) Elemental composition of marine Prochlorococcus and Synechococcus: implications for the ecological stoichiometry of the sea. Limnol Oceanogr 48:1721-1731

Bessey OA, Lowry OH, Brock MJ (1946) A method for the rapid determination of alkaline phosphatase with five cubic millimeters of serum. J Biol Chem 164:321-329

Bjorkman K, Karl DM (1994) Bioavailability of inorganic and organic phosphorus compounds to natural assemblages of microorganisms in Hawaiian coastal waters. Mar Ecol
Prog Ser 111:265-273

Bjorkman KM, Karl DM (2003) Bioavailability of dissolved organic phosphorus in the euphotic zone at Station ALOHA, North Pacific Subtropical Gyre. Limnol Oceanogr 48:1049-1057

Bjorkman K, Thomson-Bulldis AL, Karl DM (2000) Phosphorus dynamics in the North Pacific Subtropical Gyre. Aquat Microb Ecol 22:185-198

Bruns A, Nubel U, Cypionka H, Overmann J (2003) Effect of signal compounds and incubation conditions on the culturability of freshwater bacterioplankton. Appl Environ Microbiol 69:1980-1989

Cavender-Bares KK, Karl DM, Chisholm SW (2001) Nutrient gradients in the western North Atlantic Ocean: relationship to microbial community structure and comparison to patterns in the Pacific Ocean. Deep-Sea Res I 48: 2373-2395

Donald KM, Scanlan DJ, Carr NG, Mann NH, Joint I (1997) Comparative phosphorus nutrition of the marine cyanobacterium Synechococcus WH7803 and the marine diatom Thalassiosira weissflogii. J Plankton Res 19: 1793-1813

Dufresne A, Salanoubat M, Partensky F, Artiguenave F and 17 others (2003) Genome sequence of the cyanobacterium Prochlorococcus marinus SS120, a nearly minimal oxyphototrophic genome. Proc Natl Acad Sci USA 100: 10020-10025

Dyhrman ST, Webb EA, Anderson DM, Moffett JW, Waterbury JB (2002) Cell-specific detection of phosphorus stress in Trichodesmium from the western North Atlantic. Limnol Oceanogr 47:1832-1836

Fuller NJ, Marie D, Partensky F, Vaulot D, Post A, Scanlan DJ (2003) Clade-specific 16S rDNA oligonucleotides reveal the predominance of a single marine Synechococcus clade throughout a stratified water column in the Red Sea. Appl Environ Microbiol 69:2430-2443

Fuller NJ, West NJ, Marie D, Yallop M, Rivlin T, Post AF, Scanlan DJ (2005) Dynamics of community structure and phosphate status of picocyanobacterial populations in the Gulf of Aqaba, Red Sea. Limnol Oceanogr 50: 363-375

Graziano LM, Geider RJ, Li WKW, Olaiziola M (1996) Nitrogen limitation of North Atlantic phytoplankton: analysis of physiological condition in nutrient enrichment experiments. Aquat Microb Ecol 11:53-64

Grossman AR, Schaefer MR, Chiang GG, Collier JL (1994) The responses of cyanobacteria to environmental conditions: light and nutrients. In: Bryant DA (ed) The molecular biology of cyanobacteria. Kluwer Academic Publishers, Amsterdam, p 641-675

Heldal M, Scanlan DJ, Norland S, Thingstad F, Mann NH (2003) Elemental composition of single cells of various strains of Prochlorococcus and Synechococcus using X-ray microanalysis. Limnol Oceanogr 48:1732-1743

Hirani TA, Suzuki I, Norio M, Hayashi H, Eaton-Rye JJ (2001) Characterization of a two-component signal transduction system involved in the induction of alkaline phosphatase under phosphate-limiting conditions in Synechocystis sp. PCC 6803. Plant Mol Biol 45:133-144

Karl DM, Yanagi K (1997) Partial characterization of the dissolved organic phosphorus pool in the oligotrophic North Pacific Ocean. Limnol Oceanogr 42:1398-1405

Karl DM, Letelier R, Tupas L, Dore JE, Christian J, Hebel DV (1997) The role of nitrogen fixation in biogeochemical cycling in the subtropical North Pacific Ocean. Nature 388:533-538

Karl DM, Bidigare RR, Letelier RM (2001) Long term changes 
in plankton community structure and productivity in the subtropical North Pacific Ocean: the domain shift hypothesis. Deep Sea Res II 48:1449-1470

Kim S, Makino K, Amemura M, Shinagawa H, Nakata A (1993) Molecular analysis of the phoH gene, belonging to the phosphate regulon in Escherichia coli. J Bacteriol 175: 1316-1324

Kolowith LC, Ingall ED, Benner R (2001) Composition and cycling of marine organic phosphorus. Limnol Oceanogr 46:309-320

Li H, Veldhuis MJW, Post AF (1998) Alkaline phosphatase activities among planktonic communities in the northern Red Sea. Mar Ecol Prog Ser 173:107-115

Mann EL, Ahlgren N, Moffett JW, Chisholm SW (2002) Copper toxicity and cyanobacteria ecology in the Sargasso Sea. Limnol Oceanogr 47:976-988

Mary I, Vaulot D (2003) Two-component systems in Prochlorococcus MED4: genomic analysis and differential expression under stress. FEMS Microbiol Lett 226: 135-144

Michaels AF, Olson D, Sarmiento JL, Ammerman JW and 5 others (1996) Inputs, losses and transformations of nitrogen and phosphorus in the pelagic North Atlantic Ocean. Biogeochemistry 35:181-226

Mills MM, Ridame C, Davey M, La Roche J, Geider RJ (2004) Iron and phosphorus co-limit nitrogen fixation in the eastern tropical North Atlantic. Nature 429:292-294

Monaghan EJ, Ruttenberg KC (1999) Dissolved organic phosphorus in the coastal ocean: reassessment of available methods and seasonal phosphorus profiles from the Eel River Shelf. Limnol Oceanogr 44:1702-1714

Moore LR, Chisholm SW (1999) Photophysiology of the marine cyanobacterium Prochlorococcus: ecotypic differences among cultured isolates. Limnol Oceanogr 44: $628-638$

Moore LR, Rocap G, Chisholm SW (1998) Physiology and molecular phylogeny of coexisting Prochlorococcus ecotypes. Nature 393:464-467

Moore LR, Post AF, Rocap G, Chisholm SW (2002) Utilization of different nitrogen sources by the marine cyanobacteria, Prochlorococcus and Synechococcus. Limnol Oceanogr 47:989-996

Moutin T, Thingstad TF, Van Wambeke F, Marie D, Slawyk G, Raimbault P, Claustre H (2002) Does competition for nanomolar phosphate supply explain the predominance of the cyanobacterium Synechococcus? Limnol Oceanogr 47: 1562-1567

Murphy S, Riley JP (1962) A modified single solution method for the determination of phosphate in natural waters. Anal Chim Acta 27:31-36

Palenik B, Brahamsha B, Larimer FW, Land M and 11 others (2003) The genome of a motile marine Synechococcus. Nature 424:1037-1042

Parpais J, Marie D, Partensky F, Morin P, Vaulot D (1996) Effect of phosphorus starvation on the cell cycle of the photosynthetic prokaryote Prochlorococcus spp. Mar Ecol Prog Ser 132:265-274

Partensky F, Blanchot J, Vaulot D (1999) Differential distribution and ecology of Prochlorococcus and Synechococcus in oceanic waters: a review. In: Charpy L, Larkum AWD (eds) Marine cyanobacteria. Bull Inst Oceanogr Monaco 19: $457-475$

Ray JM, Bhaya D, Block MA, Grossman AR (1991) Isolation, transcription, and inactivation of the gene for an atypical alkaline phosphatase of Synechococcus sp. strain PCC 7942. J Bacteriol 173:4297-4309

Rippka R, Coursin T, Hess W, Lichtlé C and 6 others (2000)
Prochlorococcus marinus Chisholm et al. 1992, subsp. nov. pastoris, strain PCC9511, the first axenic chlorophyll $a_{2} / b_{2}$-containing cyanobacterium (Oxyphotobacteria). Int J Syst Evol Microbiol 50:1833-1847

Ritchie RJ, Trautman DA, Larkum AWD (2001) Phosphate limited cultures of the cyanobacterium Synechococcus are capable of very rapid, opportunistic uptake of phosphate. New Phytol 152:189-201

Rocap G, Moore LR, Chisholm SW (1999) Molecular phylogeny of Prochlorococcus ecotypes. In: Charpy L, Larkum AWD (eds) Marine cyanobacteria. Bull Inst Oceanogr Monaco 19:107-116

Rocap G, Distel DL, Waterbury JB, Chisholm SW (2002) Resolution of Prochlorococcus and Synechococcus ecotypes by using 16S-23S ribosomal DNA internal transcribed spacer sequences. Appl Environ Microbiol 68:1180-1191

Rocap G, Larimer FW, Lamerdin J, Malfatti S and 20 others (2003) Genome divergence in two Prochlorococcus ecotypes reflects oceanic niche differentiation. Nature 424 : 1042-1047

Scanlan DJ, West NJ (2002) Molecular ecology of the marine cyanobacterial genera Prochlorococcus and Synechococcus. FEMS Microbiol Ecol 40:1-12

Scanlan DJ, Mann NH, Carr NG (1993) The response of the picoplanktonic marine cyanobacterium Synechococcus species WH7803 to phosphate starvation involves a protein homologous to the periplasmic phosphate-binding protein of Escherichia coli. Mol Microbiol 10:181-191

Scanlan DJ, Bourne JA, Mann NH (1997a) A putative transcriptional activator of the Crp/Fnr family from the marine cyanobacterium Synechococcus sp. WH7803. J Appl Phycol 8:565-567

Scanlan DJ, Silman NJ, Donald KM, Wilson WH, Carr NG, Joint I, Mann NH (1997b) An immunological approach to detect phosphate stress in populations and single cells of photosynthetic picoplankton. Appl Environ Microbiol 63: 2411-2420

Sieracki ME, Poulton NJ, Crosbie N (2004) Automated isolation techniques for microalgae. In: Andersen RA, Millie D (eds) Algal culture techniques. Academic Press, New York

Suzuki S, Ferjani A, Suzuki I, Murata N (2004) The SphS-SphR two component system is the exclusive sensor for the induction of gene expression in response to phosphate limitation in Synechocystis. J Biol Chem 279: $13234-13240$

Thingstad TF, Rassoulzadegan F (1995) Nutrient limitations, microbial food webs, and 'biological C-pumps': suggested interactions in a P-limited Mediterranean. Mar Ecol Prog Ser 117:299-306

Toledo G, Palenik B (1997) Synechococcus diversity in the California Current as seen by RNA polymerase (rpoC1) gene sequences of isolated strains. Appl Environ Microbiol 63:4298-4303

Toledo G, Palenik B, Brahamsha B (1999) Swimming marine Synechococcus strains with widely different photosynthetic pigment ratios form a monophyletic group. Appl Environ Microbiol 65:5247-5251

Urbach E, Distel D, Scanlan DJ, Waterbury JB, Chisholm SW (1998) Rapid diversification of marine picophytoplankton with dissimilar light harvesting structures inferred from sequences of Prochlorococcus and Synechococcus (Cyanobacteria). J Mol Evol 46:188-201

Vaulot D, Partensky F (1992) Cell cycle distributions of prochlorophytes in the north western Mediterranean Sea. Deep-Sea Res 39:727-742

Vaulot D, LeBot N, Marie D, Fukai E (1996) Effect of phospho- 
rus on the Synechococcus cell cycle in surface Mediterranean waters during summer. Appl Environ Microbiol 62: 2527-2533

Wagner K, Masepohl B, Pistorius E (1995) The cyanobacterium Synechococcus sp. strain PCC 7942 contains a second alkaline phosphatase encoded by phoV. Microbiology 141:3049-3058

Wanner BL (1996) Phosphorus assimilation and control of the phosphate regulon. In: Neidhardt FC, Curtiss III R, Ingraham JL, Lin ECC and 6 others (eds) Escherichia coli and Salmonella: cellular and molecular biology. ASM Press, Washington, DC, p 1357-1381

Waterbury JB, Watson SW, Valois FW, Franks DG (1986) Biological and ecological characterization of the marine

Editorial responsibility: Jim W. Ammerman,

New Brunswick, New Jersey, USA unicellular cyanobacteria Synechococcus. Can Bull Fish Aquat Sci 214:71-120

West NJ, Scanlan DJ (1999) Niche-partitioning of Prochlorococcus populations in a stratified water column in the eastern North Atlantic Ocean. Appl Environ Microbiol 65: $2585-2591$

West NJ, Schonhuber WA, Fuller NJ, Amann RI, Rippka R, Post AF, Scanlan DJ (2001) Closely related Prochlorococcus genotypes show remarkably different depth distributions in two oceanic regions as revealed by in situ hybridization using 16S rRNA-targeted oligonucleotides. Microbiology 147:1731-1744

Wu J, Sunda W, Boyle E (2000) Phosphate depletion in the western North Atlantic Ocean. Science 289:759-762

Submitted: August 26, 2004; Accepted: April 26, 2005

Proofs received from author(s): June 8, 2005 